\title{
Scientific production of the International Classification for Nursing Practice: a bibliometric study
}

\author{
Produção científica da Classificação Internacional para a Prática de Enfermagem: estudo bibliométrico
} La producción científica de la Clasificación Internacional para la Práctica de Enfermería: un estudio bibliométrico

\section{Patrícia Josefa Fernandes Beserra', Gabriela Lisieux Lima Gomes', Márcia Cristina de Figueiredo Santos', Greicy Kelly Gouveia Dias Bittencourt', Maria Miriam Lima da Nóbrega'}

' Universidade Federal da Paraíba. João Pessoa, Paraíba, Brazil.

How to cite this article:

Beserra PJF, Gomes GLL, Santos MCF, Bittencourt GKGD, Nóbrega MML Scientific production

of the International Classification for Nursing Practice: a bibliometric study. Rev Bras Enferm [Internet]. 2018;71(6):2860-8.

DOI: http://dx.doi.org/10.1590/0034-7167-2017-0411

Submission: 06-06-2017 Approval: 01-27-2018

\begin{abstract}
Objective: To describe the scientific production of the International Classification for Nursing Practice throughout dissertations and theses published by nurses in Brazil from 1996 to 2016. Method: A bibliometric, descriptive, quantitative documentary study, carried out from October/2015 to July/2016 on the sites of the Center of Studies and Research in Nursing (CEPEn), at the thesis and dissertation banks of the Coordination of Improvement of Higher Education Personnel and of the Plataforma Sucupira (Sucupira Platform). Results: There were 108 productions, 30 theses and 78 dissertations. In 2014, there was the largest number of publications (19). The Graduate Program in Nursing of the Universidade Federal da Paraíba had the highest number of productions (23). Regarding the theme, the use in clinical practice was highlighted (69), followed by the elaboration of terminology subsets (17). Conclusion: The Brazilian scientific production setting on ICNP ${ }^{\circledR}$ is expressive, evidencing this system as a tool that allows the provision of systematic care.
\end{abstract}

Descriptors: Nursing; Classification; Standardized Nursing Terminology; Bibliometrics; Health.

\section{RESUMO}

Objetivo: Descrever a produção científica da Classificação Internacional para a Prática de Enfermagem a partir das dissertações e teses publicadas por enfermeiros no Brasil, no período de 1996 a 2016. Método: Estudo bibliométrico, descritivo, de abordagem quantitativa documental, realizado de outubro/2015 a julho/2016 nos sites do Centro de Estudos e Pesquisas em Enfermagem, nos bancos de teses e dissertações da Coordenação de Aperfeiçoamento de Pessoal de Nível Superior e da Plataforma Sucupira. Resultados: Foram encontradas 108 produções, sendo 30 teses e 78 dissertações. Em 2014, houve o maior número de publicações (19). O Programa de Pós-Graduação em Enfermagem, Universidade Federal da Paraíba, teve o maior número de produções (23). Em relação à temática, destacou-se o uso na prática clínica (69), seguida da elaboração de subconjuntos terminológicos (17). Conclusão: O cenário da produção científica brasileira sobre a CIPE ${ }^{\circledast}$ é expressivo, evidenciando esse sistema como instrumento que possibilita a prestação de cuidados sistematizados.

Descritores: Enfermagem; Classificação; Terminologia Padronizada em Enfermagem; Bibliometria; Saúde.

\section{RESUMEN}

Objetivo: Describir la producción científica de la Clasificación Internacional para la Práctica de Enfermería a partir de las disertaciones y tesis publicadas por enfermeros en Brasil en el período de 1996 a 2016. Método: Estudio bibliométrico, descriptivo, de abordaje cuantitativo documental, realizado de octubre/2015 a julio/2016 en los sitios del Centro de Estudios e Investigaciones en Enfermería, en los bancos de tesis y disertaciones de la Coordinación de Perfeccionamiento de Personal de Nivel Superior y de la Plataforma Sucupira. Resultados: Se encontraron 108 producciones, siendo 30 tesis y 78 disertaciones. En 2014, hubo el mayor número de publicaciones, 19. El Programa de Post-Graduación en Enfermería de la Universidade Federal de Paraíba tuvo el mayor número de producciones, 23. En relación con la temática, se destacó el uso en la práctica clínica (69), 
seguida de la elaboración de Subconjuntos terminológicos (17). Conclusión: El escenario de la producción científica brasileña sobre la CIPE ${ }^{\circledast}$ es expresivo, evidenciando ese sistema como instrumento que posibilita la prestación de cuidados sistematizados. Descriptores: Enfermería; Clasificación; Terminología Normalizada de Enfermería; Bibliometría; Salud.

\section{INTRODUCTION}

Nursing, as a science and profession, requires notoriety and recognition of professional actions, so that nurses are constantly seeking scientific knowledge and improvements in the quality of care provided. An important tool for this is the application of the Nursing Process through the use of classification systems for Nursing Practice ${ }^{(1)}$.

Therefore, the use of professional practice classification systems is fundamental, from the planning of Nursing care to the implementation and assessment of the same, in order to favor professional recognition from the standardized and quality record ${ }^{(2)}$.

In Nursing, there are classification systems developed and related to some of the phases of the Nursing Process, which make it possible to document stages, diagnoses, outcomes and Nursing interventions. Among the classification systems developed in Nursing, the most commonly used and known are the NANDA-I Taxonomy, the NIC - Nursing Interventions Classification, the NOC - Nursing Outcomes Classification and the International Classification for Nursing Practice (ICNP ${ }^{\circledR}$.

$\mathrm{ICNP}^{\circledR}$ is considered as a "standardized, broad and complex terminology, capable of representing the world nursing practice"(3); was developed by the International Council of Nurses (ICN) as a classification system that allows the development of a standardized, precise and objective language, guaranteeing the continuity of care provided by the Nursing team ${ }^{(4)}$.

$\mathrm{ICNP}^{\circledast}$ aims to facilitate communication between nurses and the implementation of the phases of the Nursing Process, representing a way of improving Nursing record, user assistance and professional strengthening ${ }^{(5)}$, in addition, the use of ICNP ${ }^{\circledast}$ brings challenges that encourage nurses' capacity for reflection and action, allowing clinical reasoning and critical vision, collaborating in the improvement of knowledge of these professionals $^{(6)}$.

This classification has, in its history, nine elaborate versions. The Alpha version was published in 1996, which contained two classifications composing two conceptual pyramids: the Classification of the Nursing Phenomena, monoaxial and hierarchical; and the Classification of Nursing Interventions, multiaxial, with the organization of terms by axes ${ }^{(7)}$. Then, the Beta and Beta 2 versions of ICNP ${ }^{\circledast}$ were released in 1999 and 2001, respectively, with a multiaxial approach, which allowed the combination of concepts of the axes and formed the basis of terms diversification to bring International Classification ${ }^{(8)}$. In the latter two versions, the second being considered more as a revision of the first one than a version of ICNP ${ }^{\circledR}$, the denomination of the Nursing Interventions Classification became Nursing Actions Classification, in order to cover the performance of nurses in practice and not only target an action developed in response to a diagnosis. The said classifications were constituted containing eight axes each ${ }^{(7)}$.

$\mathrm{ICNP}^{\circledR}$ version 1.0 was launched in 2005 in order to meet the needs of nurses who, when using the previous version, did not reach the goal of a unified language system in Nursing. It was built using Web Ontology Language (WOL) in Protegé software. The structure of version 1.0 contained a single classification structure composed by the Seven-Axis Model and a formal, ontological approach to compose diagnoses, outcomes and Nursing Interventions, which differentiates ICNP ${ }^{\circledR}$ from other Nursing classifications and facilitates the organization and access to ICNP ${ }^{\circledast}$ terminology subsets or ICNP ${ }^{\circledast}$ catalogs $^{(7)}$.

ICNP ${ }^{\circledast}$ terminology subsets or ICNP ${ }^{\bowtie}$ catalogs are groupings of pre-elaborated statements of diagnoses, outcomes, and nursing interventions targeted to a specific clientele, to a health priority or to a nursing phenomenon ${ }^{(5)}$. They can facilitate the exchange of data between populations of different geographic, linguistic and environmental realities. The possibility of linking terms (primitive concepts) of the different axes to elaborate pre-coordinated concepts of Nursing diagnoses, outcomes and interventions characterized ICNP ${ }^{\circledast}$ as a combinatory and enumerative terminology $y^{(5)}$.

The following versions maintained the multiaxial representation of the Seven-Axis Model and presented pre-coordinated concepts. The last version of ICNP ${ }^{\circledast}$ has 4,326 terms, of which 2,401 are primitive concepts, 1,915 pre-coordinated concepts, and 10 Organization Concepts (OC) of the other terms of the classification, considering their abstraction capabilities ${ }^{(7)}$.

In view of the historical evolution and achievements of $I C^{\circledast}$ and the understanding that the use of classification systems guarantees a practice based on scientific knowledge and determines the quality of a complex care to be provided, reflection on the construction of knowledge, in different graduate programs in which nurses carry out their training from the use of this classification system.

\section{OBJECTIVE}

To describe the scientific production of the International Classification for Nursing Practice throughout dissertations and theses published by nurses in Brazil.

\section{METHOD}

\section{Ethical aspects}

Because it was a bibliometric study, there was no need for approval by an Ethics Committee in Research with Human Beings. However, it should be noted that the information selected for analysis went through the peer review to attest the reliability of the results. 


\section{Design, place of study and period}

This is a descriptive bibliometric study, with a quantitative documentary approach. Bibliometrics consists of a type of study that quantifies scientific production and communication with the aim of disseminating works, propagating publications, productivity of authors and institutions, demonstrating the growth of science and the impact of publications on the international setting ${ }^{(9)}$.

According to the methodological description of the study, a search was made in the Catalogs of Thesis and Dissertation of CEPEn/ABEn (Brazilian Nursing Association) ${ }^{(10)}$ from the years 1996 to 2016, in the theses database from October 2015 to July 2016 and dissertations from the Coordination of Improvement of Higher Education Personnel (CAPES) ${ }^{(11)}$, until the year 2016, and in the dissertation and thesis bank of the Platforma Sucupira ${ }^{(12)}$, from the years 2012 to 2016 , using the descriptors "Nursing", "Health" and "Classification", and the keyword "ICNP". The selection of the studies was conditioned to the appearance of the minimum combination between the descriptor "Classification" and another descriptor and or keyword in the productions abstracts.

\section{Population or sample; inclu-} sion and exclusion criteria

The inclusion criteria for selection of the sample were as follows: theses and dissertations describing the use of ICNP ${ }^{\varpi}$ in the Nursing and Health Practice, and national productions in the period of publication between 1996 and 2016. The start period is justified, considering that the publication of the first version of ICNP ${ }^{\circledast}$ dates from 1996, although it began its development in 1989 . The exclusion criteria were: productions that did not address the theme of interest and that were not available online.

\section{Study protocol}

The methodological steps of the study are presented in Figure 1.

A tool was used to record the information contained in the productions, which included: identification data of theses and dissertations (title, authorship, orientation, title, type of production, descriptors/keywords, year, institution, area of knowledge); objective/research question of the studies, methodology and, finally, results and observations/ impressions of the studies assessed.

\section{Results analysis and statistics}

Based on the information contained in the tool, the following variables were included: authorship, title, type of production, orientation, coorientation, year of publication, Graduate Program, type of study, theoretical and methodological frameworks, $\mathrm{ICNP}^{\circledR}$ version used and production. In the variable "theme" of productions, the following categories were found: Validation studies; Terminology subset; Use in clinical practice; Ontologies and information systems; and Vocational training. Next, the descriptive statistical analysis was performed, with records of the frequencies of the information obtained. The data were confronted and correlated and presented in the form of graphs and tables.

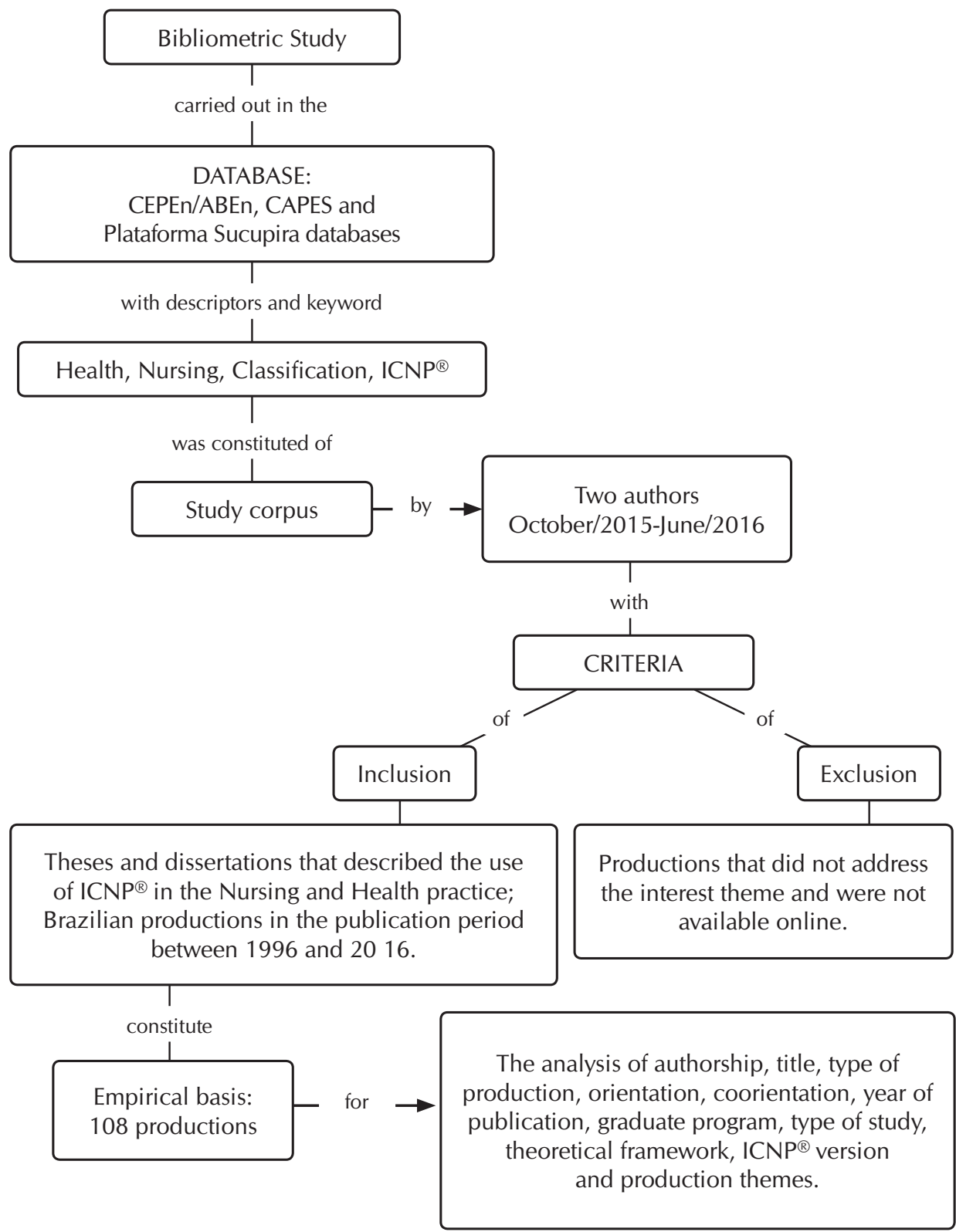

Figure 1 - Methodological description of the study, João Pessoa, Paraíba, Brazil, 2016 


\section{RESULTS}

A total of 136 scientific productions of theses and dissertations from the Nursing and Health areas were identified, from 1999 to 2016, of which 108 used ICNP ${ }^{\circledast}, 23$ cited ICNP ${ }^{\circledast}$ in the review of the literature and 5 mentioned the acronym ICNP, however, not referring to the International Classification for Nursing Practice. Thus, the empirical basis of the study consisted of 108 productions, of which 30 doctoral theses and 78 master's dissertations. Figure 2 presents, in absolute numbers, the distribution of theses and dissertations production, by years of production.

As for the year of publication, 2014 was the year in which more studies were published (19 publications), being 10 dissertations and 9 theses; followed by the years of 2012 (17 publications), with 14 dissertations and 3 theses; 2015 (12 publications) with 8 dissertations and 4 theses; and 2013 (10 publications) with 8 dissertations and 2 theses.

Thirty-five graduate programs were identified, of which 29 were in the Nursing area and 6 in other areas (Health Promotion, Biomedical Engineering, Collective Health, Health Care Sciences, Child and Adolescent Health, Health Technology).
The Graduate Program in Nursing at the Universidade Federal da Paraíba (UFPB) was the one that most presented production of theses and dissertations with 23 (21.3\%), followed by the Graduate Program in Health Technology of the Pontifícia Universidade Católica do Paraná (PUCPR) with 13 (12.0\%) and the Graduate Program in Nursing at the Universidade de São Paulo School of Nursing with 9 (8.3\%).

Regarding the geographic region of the Graduate Programs, the Northeast and Southeast presented, respectively, 41 (37.9\%) productions of theses and dissertations from the Nursing and Health areas that use ICNP ${ }^{\circledR}$, followed by the region South region with $25(23.1 \%)$ and $1(0.9 \%)$ in the Center-West region.

According to the production theme, the most used was the use in clinical practice (69 productions), followed by the terminology subsets (17 productions), as shown in Figure 3, and the most used versions were ICNP ${ }^{\circledR} 1.0$ (22 productions), version 2.0 (13 productions) and version 2011 (13 productions), in addition to the vocabulary inventory $\mathrm{ICNPCH}^{\circledR}$ - International Classification of Nursing Practices in Collective Health (19 productions). It should be noted that some studies used more than one version of ICNP ${ }^{\circledR}$ and 27 studies did not mention the version used of the ICNP.

Regarding the variable "type of study", the highest frequency was observed in the descriptive study, with 46 studies. The second highest frequency was the exploratory research, with 37 studies. While methodological and documentary research were contemplated in 24 and 11 studies, respectively. Regarding the approach, the predominant was the quantitative with 21 studies.

The distribution of productions, according to the theoretical framework, was concentrated in the Horta's Basic Human Needs Theory, with 14 studies; followed by the Theory of Praxis Intervention in Collective Health Nursing (TIPESC), based on three studies and Henderson's Nursing Need Theory with two studies.

Table 1 - Distribution of theses and dissertations production from the Nursing and Health areas that use ICNP ${ }^{\circledR}$ according to region and graduate program, João Pessoa, Paraíba, Brazil, 2016

\begin{tabular}{|c|c|c|c|c|c|c|c|}
\hline \multirow{2}{*}{ Region } & \multirow{2}{*}{ Instituton } & \multirow{2}{*}{ Program } & \multicolumn{2}{|c|}{ Dissertations } & \multirow{2}{*}{ Theses } & \multirow{2}{*}{$\mathbf{F}$} & \multirow{2}{*}{$\%$} \\
\hline & & & A & $\mathbf{P}$ & & & \\
\hline \multirow[t]{6}{*}{ Northeast } & $\begin{array}{l}\text { Universidade Federal da } \\
\text { Paraíba-UFPB }\end{array}$ & $\begin{array}{l}\text { Graduate Program in Nursing - Master's and Doctoral } \\
\text { Degrees }\end{array}$ & 19 & - & 04 & 23 & 21.3 \\
\hline & \multirow{2}{*}{$\begin{array}{l}\text { Universidade Federal de } \\
\text { Pernambuco-UFPE }\end{array}$} & Graduate Program in Nursing - Master's and Doctoral Degrees & 01 & - & - & 02 & 1.9 \\
\hline & & $\begin{array}{l}\text { Graduate Program in Child and Adolescent Health - Master's } \\
\text { and Doctoral Degrees }\end{array}$ & - & - & 01 & & \\
\hline & $\begin{array}{l}\text { Universidade de Pernambuco/ } \\
\text { Universidade Estadual da } \\
\text { Paraíba-FESP-UPE/UEPB }\end{array}$ & $\begin{array}{l}\text { Associate Program of Graduate Studies of the Universidade } \\
\text { de Pernambuco and the Universidade Estadual da Paraíba } \\
\text { (PAPGENF-UPE/UEPB) - Associate Master's Degree in Nursing }\end{array}$ & 01 & - & - & 01 & 0.9 \\
\hline & $\begin{array}{l}\text { Universidade Estadual do } \\
\text { Ceará-UECE }\end{array}$ & $\begin{array}{l}\text { Graduate Program in Clinical Care in Nursing and Health - } \\
\text { Master's and Doctoral Degrees }\end{array}$ & 03 & - & - & 03 & 2.8 \\
\hline & $\begin{array}{l}\text { Universidade Federal do } \\
\text { Maranhão-UFMA }\end{array}$ & Graduate Program in Nursing - Master's Degree & 02 & - & - & 02 & 1.9 \\
\hline
\end{tabular}




\begin{tabular}{|c|c|c|c|c|c|c|c|}
\hline \multirow{2}{*}{ Region } & \multirow{2}{*}{ Instituton } & \multirow{2}{*}{ Program } & \multicolumn{2}{|c|}{ Dissertations } & \multirow{2}{*}{-Theses } & \multirow{2}{*}{$\mathbf{F}$} & \multirow{2}{*}{$\%$} \\
\hline & & & A & $\mathbf{P}$ & & & \\
\hline & $\begin{array}{l}\text { Universidade Federal do Rio } \\
\text { Grande do Norte-UFRN }\end{array}$ & $\begin{array}{l}\text { Graduate Program in Nursing - Master's and Doctoral } \\
\text { Degrees }\end{array}$ & - & - & 02 & 02 & 1.9 \\
\hline & $\begin{array}{l}\text { Universidade Federal da } \\
\text { Bahia-UFBA }\end{array}$ & $\begin{array}{l}\text { Graduate Program in Nursing - Master's and Doctoral } \\
\text { Degrees }\end{array}$ & - & - & 01 & 01 & 0.9 \\
\hline & $\begin{array}{l}\text { Universidade Federal do } \\
\text { Piauí-UFPI }\end{array}$ & Graduate Program in Nursing - Master's Degree & 01 & - & - & 01 & 0.9 \\
\hline & $\begin{array}{l}\text { Universidade Federal de } \\
\text { Alagoas-UFAL }\end{array}$ & Graduate Program in Nursing - Master's Degree & 01 & - & - & 01 & 0.9 \\
\hline & $\begin{array}{l}\text { Universidade Federal do } \\
\text { Ceará-UFCE }\end{array}$ & Graduate Program in Nursing & 04 & - & 01 & 05 & 4.7 \\
\hline Subtotal & & & & & & 41 & 38.1 \\
\hline \multirow[t]{14}{*}{ Southeast } & $\begin{array}{l}\text { Universidade de São Paulo- } \\
\text { EEUSP/SP }\end{array}$ & Graduate Program in Nursing & 02 & - & 03 & 05 & 4.7 \\
\hline & $\begin{array}{l}\text { Universidade de São Paulo- } \\
\text { EERP/RP }\end{array}$ & $\begin{array}{l}\text { Graduate Program in Fundamental Nursing - Master's and } \\
\text { Doctoral Degrees }\end{array}$ & 01 & - & 05 & 06 & 5.6 \\
\hline & $\begin{array}{l}\text { Universidade de São Paulo- } \\
\text { EEUSP/SP }\end{array}$ & $\begin{array}{l}\text { Graduate Program in Nursing - Master's and Doctoral } \\
\text { Degrees }\end{array}$ & 04 & - & 05 & 09 & 8.3 \\
\hline & $\begin{array}{l}\text { Centro Universitário São } \\
\text { Camilo }\end{array}$ & $\begin{array}{l}\text { Graduate Program - Professional Master's Degree in Nursing } \\
\text { in the care process }\end{array}$ & - & 01 & - & 01 & 0.9 \\
\hline & $\begin{array}{l}\text { Universidade de São Paulo- } \\
\text { EEUSP-EERP }\end{array}$ & Interunits Graduate Program - Master's and Doctoral Degrees & - & - & 03 & 03 & 2.8 \\
\hline & \multirow[t]{2}{*}{$\begin{array}{l}\text { Universidade Federal } \\
\text { Fluminense-UFF }\end{array}$} & $\begin{array}{l}\text { Graduate Program in Health Care Sciences - Master's } \\
\text { Degree }\end{array}$ & 02 & - & - & 02 & 1.8 \\
\hline & & $\begin{array}{l}\text { Graduate Program in Nursing - Aurora de Afonso Costa } \\
\text { Professional Master's Degree in Nursing }\end{array}$ & - & 04 & - & 04 & 3.7 \\
\hline & $\begin{array}{l}\text { Universidade Federal de } \\
\text { Minas Gerais-UFMG }\end{array}$ & $\begin{array}{l}\text { Graduate Program in Nursing - Master's and Doctoral } \\
\text { Degrees }\end{array}$ & 03 & - & - & 03 & 2.8 \\
\hline & \multirow{2}{*}{$\begin{array}{l}\text { Universidade Federal do } \\
\text { Espírito Santo-UFES }\end{array}$} & Graduate Program - Master's Degree in Public Health Care & 01 & - & - & 03 & 2.8 \\
\hline & & $\begin{array}{l}\text { Graduate Program in Nursing - Professional Master's Degree } \\
\text { in Nursing }\end{array}$ & - & 02 & - & & \\
\hline & \multirow{2}{*}{$\begin{array}{l}\text { Universidade Federal do Rio } \\
\text { de Janeiro-UFRJ }\end{array}$} & Graduate Program in Nursing - Master's and Doctoral Degrees & - & - & 01 & 02 & 1.8 \\
\hline & & $\begin{array}{l}\text { Graduate Program in Biomedical Engineering (COPPE/UFRJ) } \\
\text { - Master's and Doctoral Degrees }\end{array}$ & 01 & - & - & & \\
\hline & $\begin{array}{l}\text { Universidade de Franca- } \\
\text { UNIFRAN }\end{array}$ & $\begin{array}{l}\text { Graduate Program in Health Promotion - Master's and } \\
\text { Doctoral Degrees }\end{array}$ & 01 & - & - & 01 & 0.9 \\
\hline & $\begin{array}{l}\text { Universidade Federal de } \\
\text { Alfenas-UNIFAL }\end{array}$ & Graduate Program in Nursing - Master's Degree & 02 & - & - & 02 & 1.8 \\
\hline Subtotal & & & & & & 41 & 37.9 \\
\hline \multirow[t]{6}{*}{ South } & $\begin{array}{l}\text { Universidade Federal de Santa } \\
\text { Catarina-UFSC }\end{array}$ & $\begin{array}{l}\text { Graduate Program in Nursing - Master's and Doctoral } \\
\text { Degrees }\end{array}$ & 04 & - & 03 & 07 & 6.5 \\
\hline & $\begin{array}{l}\text { Universidade Federal do } \\
\text { Paraná-UFPR }\end{array}$ & $\begin{array}{l}\text { Graduate Program in Nursing - Master's and Doctoral } \\
\text { Degrees }\end{array}$ & 02 & - & - & 03 & 2.8 \\
\hline & & $\begin{array}{l}\text { Graduate Program in Nursing - Professional Master's Degree } \\
\text { in Nursing }\end{array}$ & - & 01 & - & & \\
\hline & $\begin{array}{l}\text { Pontifícia Universidade } \\
\text { Católica do Paraná-PUCPR }\end{array}$ & $\begin{array}{l}\text { Graduate Program in Technology and Health - Master's } \\
\text { Degree }\end{array}$ & 13 & - & - & 13 & 12.0 \\
\hline & $\begin{array}{l}\text { Universidade do Vale do Rio } \\
\text { dos Sinos-UNISINOS }\end{array}$ & Graduate Program in Nursing - Professional Master's Degree & - & 01 & - & 01 & 0.9 \\
\hline & $\begin{array}{l}\text { Universidade Estadual de } \\
\text { Maringá-UEM }\end{array}$ & $\begin{array}{l}\text { Graduate Program in Nursing - Master's and Doctoral } \\
\text { Degrees }\end{array}$ & 01 & - & - & 01 & 0.9 \\
\hline Subtotal & & & & & & 25 & 23.1 \\
\hline $\begin{array}{l}\text { Center- } \\
\text { West }\end{array}$ & Universidade de Brasília-UNB & $\begin{array}{l}\text { Graduate Program in Nursing - Master's and Doctoral } \\
\text { Degrees }\end{array}$ & 01 & - & - & 01 & 0.9 \\
\hline Subtotal & & & & & & 01 & 0.9 \\
\hline
\end{tabular}

Note: A - Academic; P - Professional; F - Frequency. 


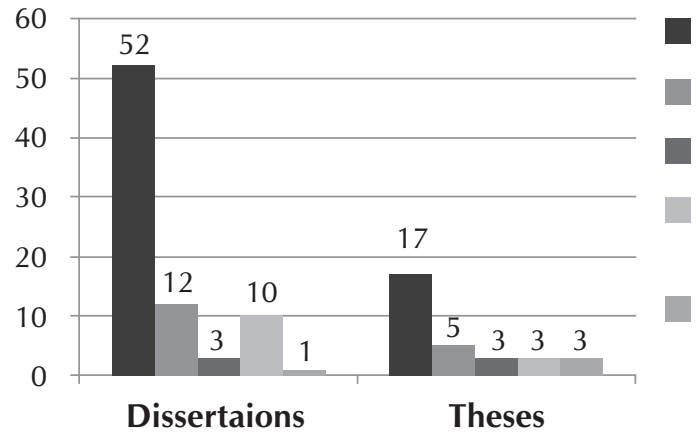

Use in clinical practice

Terminology subset

Validation study

Ontologies and information systems

Vocational training

Figure 3 - Distribution of theses and dissertations production from the Nursing and Health areas that use ICNP ${ }^{\circledast}$, according to production themes, João Pessoa, Paraíba, Brazil, 2016

\section{DISCUSSION}

The productions that used the ICNP ${ }^{\circledR}$, identified in this study, corroborate in number with the current setting of master's and doctoral degrees graduate courses in Nursing in Brazil, accounting for 89 courses, being 28 PhDs, 47 Masters' and 14 Professional Masters', of which 44 were in the Southeast Region, 17 in the South Region, 18 in the Northeast Region, 8 in the Midwest and 2 in the North Region. In this quantitative stricto sensu courses, 108 productions were identified, of which 30 doctoral theses and 78 master's dissertations were distributed in the following geographic regions: Northeast, Southeast, South and Center-West. It should be emphasized that no production was identified in the North Region, implying the need to boost this Region, which is rich in cultural and health diversities, to contribute with the development of research using the ICNP ${ }^{\circledR}$.

It was identified that the first production on $\mathrm{ICNP}^{\circledast}$ in Brazil was a master's thesis and occurred in 1999, in the Graduate Program in Nursing of the UFPB, three years after the launch of the first version of $\mathrm{ICNP}^{\circledast}$, at that time still there was no version of ICNP ${ }^{\circledast}$ translated into Brazilian Portuguese. From then on, production was found in all other years, with an increase in the indexes from 2012, reaching the apex in 2014 with 19 publications. It is inferred that this fact was due to the constant development of studies involving $\mathrm{ICNP}^{\circledR}$, in which its versions are submitted to successive processes of revisions and updates and, also, of their translation into Brazilian Portuguese from the Beta 2 version until the most recent one to $I \mathrm{CNP}^{\otimes}$ 2017. Another fact that contributed to the dissemination of the knowledge of this classification system was the creation of the version 1.1 and, from then on, the online dissemination in the site of the ICN of the versions of the ICNP ${ }^{\circledast}$.

Graduate programs that presented the largest number of theses and dissertations developed and approved were the Graduate Program in Nursing at the Universidade Federal da Paraíba (UFPB), the Graduate Program in Health Technology at the Pontifícia Universidade Católica do Paraná (PUCPR), and the Graduate Program in Nursing at the Universidade de São Paulo School of Nursing, located in the Northeast, South and Southeast regions, respectively.

In the Nursing Graduate Program of the UFPB (PPGENF/UFPB), 23 studies were identified using ICNP ${ }^{\circledast}$, being 19 dissertations and 4 theses. It is believed that the production of studies in this program is related to the involvement of teachers with this classification system since the development of the ICNPCH/ICN-ABEn Project, which occurred from 1996 to 2000, and later with the creation of the ICNP ${ }^{\circledast}$ Center program, accredited by the ICN in 2007. This Center's mission is to support the continued development of ICNP ${ }^{\circledast}$, promote its use in clinical practice, education and research in Nursing ${ }^{(3-4)}$. In view of its mission, the ICNP ${ }^{\circledast}$ Center has collaborated in the development of dissertations and theses in the PPGENF (Graduate Program in Nursing), with the construction of essential nursing databases and a nomenclature of diagnoses, outcomes and Nursing interventions for Nursing Practice in the units clinics of the University Hospital Lauro Wanderley, Universidade Federal da Paraíba (HULW/UFPB), and the development of terminology subsets of the ICNP ${ }^{\circledR}$ for Nursing Practice in specialized clinical areas and in primary care in several thematic areas: congestive heart failure ${ }^{(14)}$; oncologic pain $^{(15)}$; elderly person ${ }^{(16-17)}$; hypertensive patients attended at Basic Health Units ${ }^{(18)}$; prostatectomy ${ }^{(19)}$; institutionalized elderly person $^{(20)}$; diabetes mellitus in specialized care $^{(21)}$.

Likewise, in order to contribute to the development of ICNP in Brazil, researchers from the Graduate Program in Health Technology, the Pontifícia Universidade Católica do Paraná (PUCPR) and the Graduate Program in Nursing, Universidade de São Paulo School of Nursing (EEUSP/SP) have been developing studies with this classification system. In the Graduate Program in Health Technology, from PUCPR, 13 dissertations were identified using ICNP ${ }^{\circledR}$ and related to the thematic areas: Circulatory system process ${ }^{(22)}$; elements of ontology in the different versions of ICNP ${ }^{\circledR}$ and in the ICNPCH ${ }^{\circledR}$ vocabulary inventory ${ }^{(23)}$; Nursing records $^{(24)}$; reproductive apparatus ${ }^{(25)}$; pain ${ }^{(26)}$; development of ICNP $^{\circledR}$ terminology subsets; Focuses of the corporal process ${ }^{(27)}$; Ontology ${ }^{(28)}$; post-vaccination adverse event information system $^{(29)}$. In the Graduate Program in Nursing at the EEUSP (USP Nursing School)/SP, eight studies were identified using ICNP ${ }^{\circledR}$ and related to the thematic areas: a re-reading tool of the collective face of the health-disease process ${ }^{(30)}$; addressing the health needs of the child population ${ }^{(31)}$; monitoring of the development of children $0-3$ years of age ${ }^{(32)}$; Nursing records ${ }^{(33)}$; nausea in the immediate postoperative period ${ }^{(34)}$; child development ${ }^{(35)}$; hospitalizations due to conditions sensitive to Primary Care ${ }^{(36)}$.

Among the production themes, it was observed that there was a greater use of ICNP ${ }^{\circledR}$ in clinical practice (69), considering the use of this classification as a guiding tool for the Nursing Process, which allows the structuring of diagnoses, outcomes and interventions used in care practice. In another perspective, the use of ICNP ${ }^{\circledast}$ was identified in 17 productions that structured terminology subsets, which are in constant development for use in different areas of Nursing practice.

The ICNP ${ }^{\circledast}$ as a standardized terminology and technological tool helps the nurse in describing the elements of professional practice, in the improvement of reasoning and clinical decision 
making, as well as in the communication between Nursing professionals and other areas. In addition, it favors the documentation of professional practice regarding the evaluation of Nursing as a profession and its visibility in the contribution of the health of human persons, families and human collectivities ${ }^{(7)}$.

The applicability of ICNP ${ }^{\circledast}$ to clinical practice demonstrates the commitment of Brazilian Nursing to the care process ${ }^{(20,22,24-25,27)}$. It is inferred that nurses are using theoretical-practical knowledge, specific tools and methods to promote improvement in Nursing care. It is understood that there is a quest for excellence of its actions in order to reach a professional practice resolution based on the relief of health problems, health promotion and disease prevention.

The construction of ICNP ${ }^{\circledast}$ terminology subsets represents a way of generating data to be used to support and improve clinical practice, decision-making, research and professional training. In addition, it has the potential to contribute to the worldwide expansion of ICNP ${ }^{\circledR}$ as it allows focusing on cultural, linguistic, local, regional and national variations ${ }^{(37)}$.

It is expected that the use of terminology subsets contributes to the effective implementation of the Nursing Process in professional practice, as well as to the construction of health information systems, allowing the mapping with other Nursing classification systems and resulting in the development of data that describe the Nursing work $^{(4)}$.

Regarding the versions of ICNP ${ }^{\circledast}$ used in the identified productions, a larger quantitative value was found in version 1.0 (22), which can be justified by the Seven Axes Model adopted, which allows the structuring of Nursing diagnoses, outcomes and interventions by through the use of terms that make up its axes: Focus, Judgment, Environment, Action, Time, Location and Customer. Another fact that has been observed concerns the use of ICNPCH, which is a tool of the nursing work process in Collective Health that was developed, using, as a reference, the structure of axes proposed by the ICNP ${ }^{\circledR}$ Beta version and has been used and has favored the organization of the work, bringing benefits in the action of Nursing care, management and research ${ }^{(38)}$.

It should be noted that the ICNPCH/ICN-ABEn project, developed in the period from 1996 to 2000, resulted in a collective inventory of Nursing in Collective Health, which is not a classification system, but its purpose was to contribute to the confirmation of terms and identification of new terms, enabling the expansion of ICNP ${ }^{\circledast}$ in Brazil. Another result was the analysis of the interventions, which revealed the dimension, diversity and breadth of Nursing practices within the Brazilian health system ${ }^{(39)}$.

Although the version of ICNP ${ }^{\circledR}$ used in most of the analyzed productions was mentioned, it was observed that 27 studies did not explain this use, which refers us to the reflection on the need to specify this fact, considering the constant development of this classification system and the importance of performing studies that meet the current setting of using terminologies that, in fact, correspond and are being used in Nursing Practice.

As to the type of study, most of the studies identified were descriptive (46) and exploratory (37), followed by methodological research (24) and quantitative approach (21). Descriptive or exploratory studies are used when little is known about a particular phenomenon. The researcher observes, describes and documents several aspects of the phenomenon, there is no manipulation of variables or search for cause and effect related to the phenomenon, describe what actually exists, determine how often this occurs and categorize the information. The results provide the knowledge base for hypotheses that guide subsequent studies ${ }^{(40)}$.

Regarding the methodological study, it is worth mentioning its use as a tool of abstraction or intervention in reality, generating as end result a representative method, such as a flow chart, protocol or a list of steps or considerations to be followed ${ }^{(41)}$. On the other hand, the quantitative approach adopts a systematic, objective and rigorous strategy to generate and refine knowledge. In this drawing, the relations between variables are quantified and deductive reasoning and generalization are used initially. The resulting knowledge is based on careful observation, measurement and interpretation of objective reality ${ }^{(40)}$, that is, it allows working with measurement in order to study the phenomenon.

As theoretical framework, the analyzed studies used more frequently the Horta's Basic Human Needs Theory. This relevant use may be related to the $\mathrm{ICNPCH}^{\otimes}$ restructuring that took place in 2006 and adopted this theoretical framework ${ }^{(38)}$ and with the fact that some hospital institutions to use as a reference for the organization of the data collection tools, as well as in the application of the Nursing Process.

In view of the dissertations and theses that have used ICNP ${ }^{\circledR}$, this study identified a design of Brazilian productions that deal with the theme, with emphasis on the variables of type of production, year of publication, graduate program, authorship, title, orientation, coorientation, type of study, theoretical framework, ICNP ${ }^{\oplus}$ version and production themes. This survey allowed the quantitative measurement of the data, which in turn favors the understanding of the perspective of using the Classification System in Brazil, as well as the possible contribution of these productions to ICNP ${ }^{\circledast}$ in the international scope, due to the way this classification comes being developed, improved and updated, opening the contributions of those who use it.

\section{Study limitations}

The number of studies identified can be overcome when considering non-notified productions and those that are in progress.

\section{Contributions to the sectors of Nursing, Health and Public Policy}

The study brings as a contribution to Nursing the evidence of ICNP ${ }^{\circledR}$ as a tool that allows the provision of systematic care and presents feasibility of use to strengthen professional practice.

\section{CONCLUSION}

The use of ICNP ${ }^{\circledR}$ has been evidenced in the course of its historical evolution, proven by the increasing visibility in the scientific field of Nursing knowledge construction. The diversity of applicability of this classification to subsidize research and practice determines the importance of adherence and appropriation of nurses to this technological tool. 
The setting of Brazilian scientific production on the use of this classification system is expressive, so that over the last three decades, since the emergence of ICNP ${ }^{\circledast}$, it was possible to identify 108 theses and dissertations reported in the virtual environment.

\section{FUNDING}

This study was financed in part by the Coordenação de Aperfeiçoamento de Pessoal de Nível Superior - Brasil (CAPES) - Finance Code 001.

\section{REFERENCES}

1. Silva MM, Moreira MC. Challenges of systematization of nursing care in palliative care in cancer: a complexity perspective. Rev Eletron Enferm[Internet]. 2010[cited 2015 Sep 22];12(3):483-90. Available from: http://dx.doi.org/10.5216/ree.v12i3.7274

2. Medeiros ACT, Nóbrega MML. Terminological subsets of the International Classification for Nursing Practice - ICNP ${ }^{\circledR}$ for sênior patients: a methodological study. O Braz J Nurs[Internet]. 2013[cited 2016 May 20];12(Suppl):590-2. Available from: http://www. objnursing.uff.br/index.php/nursing/article/view/4447

3. Garcia TR, Nóbrega MML, Coler MS. Centro CIPE ${ }^{\circledR}$ do Programa de Pós-Graduação em Enfermagem da UFPB. Rev Bras Enferm[Internet]. 2008[cited 2015 Sep 22];61(6):888-91. Available from: http://dx.doi.org/10.1590/S0034-71672008000600016

4. Garcia TR, Nóbrega MML. A terminologia CIPE $^{\circledR}$ e a participação do Centro CIPE ${ }^{\circledR}$ Brasileiro em seu desenvolvimento e disseminação. Rev Bras Enferm[Internet]. 2013[cited 2015 Sep 22];66(N.Esp):142-50. Available from: http://dx.doi.org/10.1590/ S0034-71672013000700018

5. Cubas MR, Silva SH, Rosso M. Classificação Internacional Para a Prática de Enfermagem CIPE ${ }^{\circledR}$ : uma revisão de literatura. Rev Eletron Enferm[Internet]. 2010[cited 2016 Mar 14];12(1):186-94. Available from: http://www.fen.ufg.br/revista/v12/n1/v12n1a23.htm

6. Primo CC, Trevizani CC, Tedesco JC, Leite FMC, Almeida MVS, Lima EFA. Classificação Internacional para a Prática de Enfermagem na assistência pré-natal. Enferm Foco[Internet]. 2015[cited 2016 May 20];6(1/4):17-23. Available from: http://revista.portalcofen. gov.br/index.php/enfermagem/article/view/571/253

7. Garcia TR. Classificação Internacional para a Prática de Enfermagem (CIPE $\left.{ }^{\circledR}\right)$ : versão 2017. Porto Alegre: Artmed, 2018.

8. Marucci AR, Caro WD, Jancia L, Sansoni J. ICNP ${ }^{\circledR}$ - Classificazione Internazionale per la pratica: origini, strutturaione e sviluppo. Prof Infermieristiche[Internet]. 2015[cited 2016 May 20];68(2):1-11. Available from: http://www.profinf.net/pro3/index.php/IN/ article/view/164

9. Gentil RC, Guia BP, Sanna MC. Organização de serviços de capelania hospitalar: um estudo bibliométrico. Esc Anna Nery[Internet]. $2011[$ cited 2016 May 20];15(1):162-70. Available from: http://www.scielo.br/pdf/ean/v15n1/23.pdf

10. Associação Brasileira de Enfermagem. Centro de Estudos e Pesquisas em Enfermagem-CEPEn. Catálogo de Teses e Dissertações[Internet]. 2015[cited 2016 May 20]. Available from: http://www.abennacional.org.br/home/tesesedissertacoescepen.htm

11. Coordenação de Aperfeiçoamento de Pessoal de Nível Superior-Capes. Banco de Teses e Dissertações[Internet]. 2015 [cited 2016 May 20]. Available from: http://bancodeteses.capes.gov.br/

12. Plataforma SUCUPIRA. Trabalhos de conclusão[Internet]. 2015[cited 2016 May 20]. Available from: https://sucupira.capes.gov.br/

13. Scochi CGS, Munari DB, Gelbcke FL, Erdmann ALI, Gutiérrez MGR, Rodrigues RAP. Pós-Graduação Stricto Sensu em Enfermagem no Brasil: avanços e perspectivas. Rev Bras Enferm[Internet]. 2013[cited 2015 Nov 13];66(N.Esp):80-9. Available from: http://dx.doi. org/10.1590/S0034-71672013000700011

14. Araújo AA, Nóbrega MML, Garcia TR. Diagnósticos e intervenções de enfermagem para pacientes portadores de insuficiência cardíaca congestiva utilizando a CIPE ${ }^{\circledR}$. Rev Esc Enferm USP[Internet]. 2013[cited 2016 Sep 14];47(2):385-92. Available from: http://dx.doi.org/10.1590/S0080-62342013000200016

15. Carvalho MWA, Nóbrega MML, Garcia TR. Process and outcomes of the development of an ICNP ${ }^{\circledR}$ Catalogue for Cancer Pain. Rev Esc Enferm USP[Internet]. 2013[cited 2016 Sep 14];47(5):1060-7. Available from: http://dx.doi.org/10.1590/S0080-623420130000500008

16. Medeiros ACT, Nóbrega MML, Rodrigues RAP, Fernandes MGM. Diagnósticos de enfermagem para idosos utilizando-se a Classificação Internacional para a Prática de Enfermagem e o modelo de vida. Rev Latino-Am Enfermagem[Internet]. 2013[cited 2016 Sep 14];21(2):[8 telas]. Available from: http://www.scielo.br/pdf/rlae/v21n2/pt 0104-1169-rlae-21-02-0523.pdf

17. Medeiros ACT, Nóbrega MML. Validation of the terminological subset of the ICNP ${ }^{\circledR}$ for the elderly. J Nurs UFPE[Internet]. 2014[cited 2016 Sep 14];8(Suppl.-3):4174-8. Available from: https://periodicos.ufpe.br/revistas/revistaenfermagem/article/view/10158

18. Nóbrega RV, Souza GLL, Brito S, Queiroga V, Nóbrega MM. Cross-mapping of terms on the records of hypertensive patients in a family health unit with ICNP ${ }^{\circledR}$. J Nurs UFPE[Internet]. 2013[cited 2016 Sep 19];7(2):321-7. Available from: https://periodicos.ufpe. br/revistas/revistaenfermagem/article/view/10239/0

19. Nascimento DM, Nóbrega MML, Carvalho MWA, Norat EM. Diagnósticos, resultados e intervenções de enfermagem para clientes hospitalizados submetidos à prostatectomia. Rev Eletron Enferm[Internet]. 2011[cited 2016 Sep 19];13(2):165-73. Available from: http://www.fen.ufg.br/revista/v13/n2/v13n2a02.htm. 
20. Oliveira JMM, Nóbrega MML, Oliveira JS. Nursing diagnosis and outcomes for the institutionalized elderly: a methodological study. O Braz J Nurs[Internet]. 2015[cited 2016 May 6];14(2):110-20. Available from: http://www.objnursing.uff.br/index.php/ nursing/article/view/5151

21. Nogueira LGF, Nóbrega MML. Construção e validação de diagnósticos de enfermagem para pessoas com diabetes na atenção especializada. Rev Esc Enferm USP[Internet]. 2015[cited 2016 Sep 19];49(1):54-60. Available from: http://dx.doi.org/10.1590/ S0080-623420150000100007

22. Cubas MR, Brondani AM, Malucelli A. Nursing diagnoses and outcomes related to the circulatory-system terms (ICNP $\left.{ }^{\circledR}\right)$ represented in an ontology. Rev Esc Enferm USP[Internet]. 2013[cited 2016 Oct 17];47(5):1068-75. Available from: http://dx.doi.org/10.1590/ S0080-623420130000500009

23. Carvalho CMG, Cubas MR, Malucelli A, Nobrega MML. Alignment of ICNP ${ }^{\circledR} 2.0$ Ontology and a proposed INCP ${ }^{\circledR}$ Brazilian Ontology. Rev Latino-Am Enfermagem[Internet]. 2014[cited 2016 Oct 17];22:499-503. Available from: http://www.scielo.br/pdf/ rlae/v22n3/0104-1169-rlae-22-03-00499.pdf

24. Gomes DC, Cubas MR, Pleis LE, Shmeil MAH, Peluci APVD. Termos utilizados por enfermeiros em registros de evolução do paciente. Rev Gaúcha Enferm[Internet]. 2016[cited 2016 Oct 17];37(1):53927. Available from: http://dx.doi.org/10.1590/1983-1447.2016.01.53927

25. Cubas MR, Carvalho CMG, Malucelli A, Denipote AGM. Mapeamento dos termos dos eixos tempo, localização, meio e cliente entre versões da CIPE $^{\circledR}$ e CIPESC ${ }^{\circledR}$. Rev Bras Enferm[Internet]. 2011[cited 2016 Oct 17];64(6):1100-5. Available from: http://www. scielo.br/pdf/reben/v64n6/v64n6a17.pdf

26. Mattei FD, Toniolo RMM, Cubas MR, Malucelli A. Uma visão da produção científica internacional sobre a classificação internacional para a prática de enfermagem. Rev Gaúcha Enferm[Internet]. 2011[cited 2016 Oct 17];32(4):823-31. Available from: http://dx.doi. org/10.1590/S1983-14472011000400025

27. Rosso M, Silva SH, Scalabrin EE. Sistema baseado em conhecimento para apoio à identificação dos focos do processo corporal da CIPE. Texto Contexto Enferm[Internet]. 2009[cited 2016 Oct 17];18:(3):523-31. Available from: http://www.scielo.br/pdf/tce/ v18n3/a16v18n3.pdf

28. Silva RR, Malucelli A, Cubas MR. Classificações de enfermagem: mapeamento entre termos do foco da prática. Rev Bras Enferm[Internet]. 2008[cited 2016 Oct 17];61(6):835-40. Available from: http://www.scielo.br/pdf/reben/v61n6/a07v61n6.pdf

29. Bisetto LHL, Cubas MR, Malucelli A. A prática da enfermagem frente aos eventos adversos pós-vacinação. Rev Esc Enferm USP[Internet]. 2011[cited 2016 Oct 17];45(5):1125-31. Available from: www.scielo.br/pdf/reeusp/v45n5/v45n5a14.pdf

30. Cubas MR, Egry EY. Práticas inovadoras em saúde coletiva: ferramenta re-leitora do processo saúde-doença. Rev Esc Enferm USP[Internet]. 2007[cited 2016 Oct 17];41(N-esp):787-92. Available from: http://www.scielo.br/pdf/reeusp/v41nspe/v41nspea07.pdf

31. Chaves MMN, Farias FCSA, Apostolico MR, Cubas MR, Egry EY. Amamentação: a prática do enfermeiro na perspectiva da Classificação Internacional de Práticas de Enfermagem em Saúde Coletiva. Rev Esc Enferm USP[Internet]. 2011 [cited 2016 Oct 17];45(1):199-205. Available from: http://www.scielo.br/pdf/reeusp/v45n1/en_28.pdf

32. Buchhorn SMM, Verissimo MDLOR. Construção de um catálogo CIPE ${ }^{\circledR}$ : acompanhamento do desenvolvimento da criança de 0 a 1 ano. Rev Enferm UFPE[Internet]. 2013[cited 2016 Oct 25];7(Esp):5055-8. Available from: https://periodicos.ufpe.br/revistas/ revistaenfermagem/article/view/11771/14110

33. Morais SCRV, Nobrega MML, Carvalho EC. Convergências, divergências e acurácia diagnóstica à luz de duas terminologias de enfermagem. Rev Bras Enferm[Internet]. 2015[cited 2016 Oct 25];68(6):1086-92. Available from: http://dx.doi.org/10.1590/0034-7167.2015680613i

34. Pompeo DA, Rossi LA, Paiva L. Content validation of the nursing diagnosis nausea. Rev Esc Enferm USP[Internet]. $2014[$ cited 2016 Oct 17];48(1):48-56. Available from: http://www.scielo.br/pdf/reeusp/v48n1/0080-6234-reeusp-48-01-48.pdf

35. Souza JM, Veríssimo MDLÓR. Desenvolvimento infantil: análise de um novo conceito. Rev Latino-Am Enfermagem[Internet]. 2015[cited 2016 Oct 25];23(6):1097-104. Available from: http://dx.doi.org/10.1590/0104-1169.0462.2654

36. Melo MD, Egry EY. Social determinants of hospitalizations for ambulatory care sensitive conditions in Guarulhos, São Paulo. Rev Esc Enferm USP[Internet]. 2014[cited 2016 Oct 17];48(N-Esp):129-36. Available from: http://www.scielo.br/pdf/reeusp/v48nspe/00806234-reeusp-48-esp-133.pdf

37. Coenen A, Kim TY. Development of terminology subsets using ICNP ${ }^{\circledR}$. Int J Med Inform[Internet]. 2010[cited 2016 Nov 10];79(7):5308. Available from: https://doi.org/10.1016/j.ijmedinf.2010.03.005

38. Cubas MR, Egry EY. International classification of nursing practices in collective health - CIPESC ${ }^{\circledR}$. Rev EsC Enferm USP[Internet]. 2008[cited 2016 Nov 10];42(1):181-6. Available from: http://dx.doi.org/10.1590/S0080-62342008000100024

39. Egry EY, Antunes MJ, Lopes MGD. Projeto CIPESC ${ }^{\circledR}$ CIE-ABEn. In: Garcia TR, Egry EY, (Orgs.). Integralidade da atenção no SUS e sistematização da assistência de enfermagem. Porto Alegre: Artmed; 2010. p.175-191.

40. Sousa VD, Driessnack M, Mendes IAC. Revisão dos desenhos de pesquisa relevantes para enfermagem. parte 1: desenhos de pesquisa quantitativa. Rev Latino-Am Enfermagem[Internet]. 2007[cited 2016 Nov 10];15(3):502-7. Available from: http://dx.doi. org/10.1590/S0104-11692007000300022

41. Cubas MR, Nóbrega MML. Atenção primária em saúde: diagnósticos, resultados e intervenções de enfermagem. Rio de Janeiro: Elsevier; 2015. 